\title{
Species identification and population structure analysis in Geranium subg. Geranium (Geraniaceae)
}

\section{Somayeh Esfandani-Bozchaloyi ${ }^{1,{ }^{*}}$, Masoud Sheidai ${ }^{1}$, Maryam Keshavarzi ${ }^{2}$ \& Zahra Noormohammadi ${ }^{3}$}

Keywords: ISSR, morphology, species identification.

Ključne besede: ISSR, morfologija, določitev vrst.

Received: 19. 6. 2017

Revision received: 5.9. 2017

Accepted: 10. 9. 2017

\begin{abstract}
Species identification is fundamentally important within the fields of biology, biogeography, ecology and conservation. The genus Geranium L. (Geraniaceae) comprises about 430 species distributed throughout most parts of the world. According to the most recent treatments, subg. Geranium is the largest subgenus with over 370 species classified in ten sections. The subg. Geranium is represented in Iran by 13 species. These species are grouped 3 sections. In spite vast distribution of many Geranium species that grow in Iran, there are not any available report on their genetic diversity, mode of divergence and patterns of dispersal.

Therefore, we performed molecular (ISSR markers) and morphological studies of 102 accessions from 13 species of Geranium (subg. Geranium) that were collected from different habitats in Iran. The aims of present study are: 1) can ISSR markers identify Geranium species, 2) what is the genetic structure of these taxa in Iran, and 3) to investigate the species inter-relationship? The present study revealed that combination of morphological and ISSR data can identify the species.
\end{abstract}

\section{Izvleček}

Določitev vrst je pomembna v biologiji, biogeografiji, ekologiji in naravovarstvu. V rod Geranium L. (Geraniaceae) uvrščamo okoli 430 vrst razširjenih po večini sveta. V skladu z najnovejšimi objavami je subg. Geranium najštevilčnejši podrod z več kot 370 vrstami, ki jih naprej delimo v deset sekcij. V Iranu v podrod Geranium uvrščamo 13 vrst in jih nadalje združujemo v tri sekcije. Navkljub številnim splošno razširjenim vrstam rodu Geranium, ki uspevajo v Iranu ne obstaja nobena raziskava o njihovi genetski raznolikosti, načinih divergence in vzorcih razširjenosti.

Zato smo izvedli molekularno (ISSR markerji) in morfološko raziskavo 102 primerkov 13 vrst rodu Geranium (subg. Geranium), ki smo jih nabrali v različnih rastiščih v Iranu. V raziskavi smo ugotavljali: 1) ali lahko z ISSR markerji ločimo vrste Geranium, 2) kakšna je genetska struktura the taksonov v Iranu in 3) kakšni so medsebojni odnosi med temi vrstami. Ugotovili smo, da s kombinacijo morofoloških in ISSR podatkov uspešno določimo vrste.

\footnotetext{
1 Faculty Life Sciences and Biotechnology, Shahid Beheshti University, Tehran, Iran. E-mail: somayehesfand@yahoo.com, msheidai@yahoo.com, msheidai@sbu.ac.ir

2 Department of Plant Sciences, Faculty of Biological Science, Alzahra University, Tehran, Iran. E-mail: neshat112000@yahoo.com, m.keshavarzi@alzahra.ac.ir

3 Department of Biology, Science and Research Branch, Islamic Azad University, Tehran, Iran. E-mail: marjannm@yahoo.com

* Corresponding author
} 


\section{Introduction}

Species delimitation is important in different biological disciplines, like ecology, biogeography, and plant conservation (Mayr 1982, Wiens 2007). Species delimitation is done by tree-based and non-tree-based approaches (Sites \& Marshall 2003). In the first method, species form distinguishing clades (phylogenetic species concept), whereas in non-tree-based method, the species are recognized on the basis of gene flow assessments (biological species concept; Pérez-Losada et al. 2005).

Wiens \& Penkrot (2002), proposed to use DNA data, morphological data and character data for species delimitation while, Knowles \& Carstens (2007) addressed how molecular data (i.e., gene trees from DNA sequence data) can be used in species delimitation. The latter authors used coalescent simulations to test the species limits and incorporated data from multiple loci. They showed the importance of population genetics in species delimitation. Similarly, Medrano et al. (2014), applied population genetics methods to the species delimitation problem in Narcissus Linnaeus (1753: 289) (Amaryllidaceae J.St.-Hil. nom. cons.) by the help of amplified fragment length polymorphism (AFLP) molecular markers.

The genus Geranium L. (Geraniaceae) comprises about 430 species distributed through out most of the world (Aedo et al. 1998b). A brief history of the generic delimitation and infra-generic classification, as well as a description of the genus, can be found in Aedo (1996). According to the currently accepted classification (Yeo 1984), Geranium is divided into three subgenera: subg. Geranium, subg. Erodioidea (Picard) Yeo, and subg. Robertium (Picard) Rouy. Most recent treatments revealed that $G$. subgen. Geranium is the largest subgenus with over 370 species (in 10 sections) (Aedo et al. 2003, 2005a, 2005b, 2007, Aedo \& Estrella 2006). Some of these sections have already been revised (Davis 1970, Carlquist \& Bissing 1976), but further studies should be done to attain a satisfactorily knowledge of subg. Geranium. The diversity of fruit-types in Geranium is greatest in the Mediterranean region (Yeo 1984, 2004). Within G. subgen. Geranium, sect. Geranium is a widespread and heterogeneous group with wide distribution patterns except tropical lowlands, deserts and polar regions, whereas G. sect. Dissecta Yeo is widely distributed in Eurasia, between the Mediterranean region and the Himalaya mountains and $G$. sect. Tuberosa (Boiss.) Reiche is present in the Mediterranean area and central parts of Asia, Western Europe and northwestern Africa. Geranium sect. Tuberosa was subdivided by Yeo (1984) into the subsections Tuberosa (Boiss.) Yeo and Mediterranea
R. Knuth based on the vegetative traits. Yeo (1984) indicated that $G$. subsect. Tuberosa was characterized by tuberose rootstock and palmatisect leaves and the highest diversity of the group is found at regions between Turkey and Iran (Aedo \& Estrella 2006, Aedo et al. 2007).

Controversy exists on the number of species in this genus, for example, there is occurring 22 annual and perennial species for this genus in Iran according to Flora Iranica (Schönbeck-Temesy 1970), but in Iran Flora (Janighorban 2009), the genus is represented by 25 species but there are not clarified sections for it (Onsori et al. 2010). Diagnostic features in infrageneric classification are related to fruit discharge methods, mericarp margin and leaves shape. In Iran there are Geranium species with carpel projection or seed ejection.

Geranium is both cross-pollinated and self-pollinated (Stebbins, 1957, 1970), and inter-specific hybrids and intermediate forms do occur in few Geranium species in the area of species overlap. Yeo (2002: 214) indicated that artificial hybrids between many species of subsect. Mediterranea (including G. ibericum and G. platypetalum) have been produced by Bremner. However, no names for these hybrids are available except Geranium $\times$ magnificum which is usually considered as a hybrid between G. ibericum (without glandular hairs) and G. platypetalum (with glandular hairs).

Previous study on species delimitation and species relationship performed in this genus (Salimi Moghadam et al. 2015) revealed that fruit characters are important for separating taxa at infra-generic rank and their results show that the species can be separated into subgenera and sections based on fruit morphology while seed micro-morphological features generally do not support the sectional taxonomy, but provide valuable characters for the delimitation at species groups, species, and infra-specific levels (Salimi Moghadam et al. 2015). Literature revealed that studies are mainly dealing with taxonomy, seed and pollen morphology, stem and leaf anatomy (Salimpour et al. 2009, Onsori et al. 2010, Salimi Moghadam et al. 2015, Keshavarzi et al. 2015, 2016, Esfandani-Bozchaloyi et al. 2017a, 2017b, 2017c, 2017d) of Geranium species but there are no attempt to study genetic diversity, ecological adaptation and intra- and inter-specific differentiation along with morphometric studies on Geranium of Iran. Therefore, we performed morphological and molecular study of 159 collected specimens of 3 section in the subg. Geranium. We try to answer the following questions: 1) Is there infra and interspecific genetic diversity among studied species? 2) Is genetic distance among these species correlated with their geographical distance? 3) What is the genetic structure of populations and taxa? 4) Is there any gene exchange between Geranium species in Iran? 


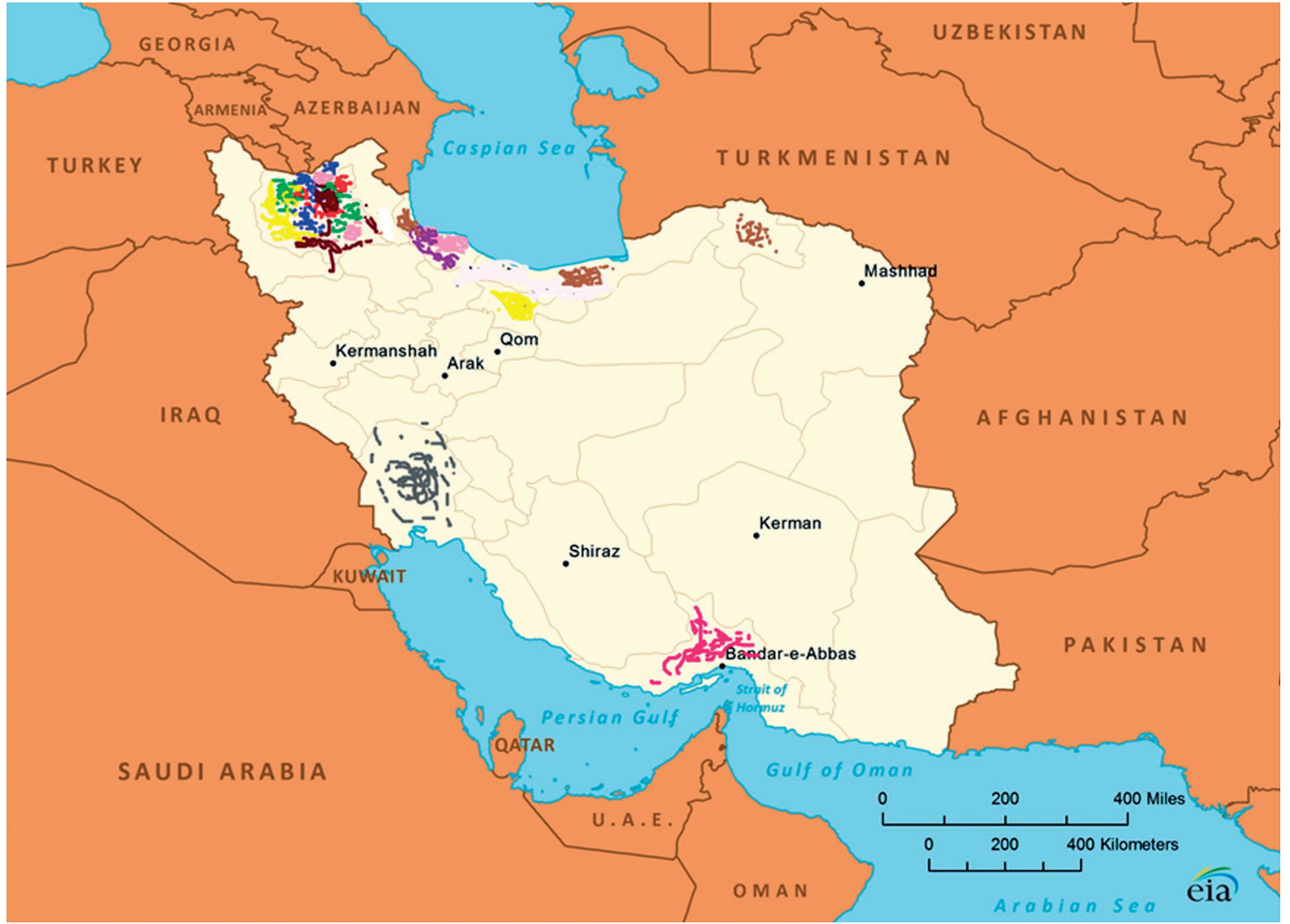

- G. dissectum, $\bullet$ G. collinum, $\bullet$ G. columbinum, $\odot$ G. rotundifolium, $\bullet$ G. persicum, $\bullet$ G. tuberosum,

- G. kotschyi, G. pratense, G. stepporum, G. sylvaticum, $\bullet$ G. platypetalum, $\bullet$ G. gracile, $\bullet$ G. ibericum

Figure 1: Distribution map in studied species.

Slika 1: Karta raž̌irjenosti preučevanih vrst.

Table 1: Geranium species and populations, their localities and voucher numbers.

Tabela 1: Vrste in populacije rodu Geranium, lokalitete in številke vavčerjev.

\begin{tabular}{|c|c|c|c|c|c|}
\hline Sp. & Locality & Latitude & Longitude & Altitude (m) & Voucher no. \\
\hline \multirow[t]{2}{*}{ 1. G. dissectum } & Guilan, Siahkal, Ezbaram & $37^{\circ} 07^{\prime} 48^{\prime \prime}$ & $49^{\circ} 54^{\prime} 04^{\prime \prime}$ & 165 & HSBU 201658 \\
\hline & Guilan, Lahijan & $37^{\circ} 07^{\prime} 08^{\prime \prime}$ & $49^{\circ} 54^{\prime} 11^{\prime \prime}$ & 159 & HSBU 201659 \\
\hline \multirow[t]{2}{*}{ 2. G. columbinum } & East Azerbaijan kaleybar cheshme ali akbar & $38^{\circ} 52^{\prime} 93^{\prime \prime}$ & $47^{\circ} 25^{\prime} 92^{\prime \prime}$ & 1133 & HSBU 201660 \\
\hline & East Azerbaijan kaleybar, Shojabad & $38^{\circ} 52^{\prime} 93^{\prime \prime}$ & $47^{\circ} 25^{\prime} 92^{\prime \prime}$ & 1139 & HSBU 201661 \\
\hline 3. G. rotundifolium & Tehran, Tuchal & $35^{\circ} 50^{\prime} 36^{\prime \prime}$ & $51^{\circ} 24^{\prime} 28^{\prime \prime}$ & 2383 & HSBU 201662 \\
\hline 4. G. collinum & Tehran, Damavand & $35^{\circ} 42^{\prime} 29^{\prime \prime}$ & $52^{\circ} 20^{\prime} 51^{\prime \prime}$ & 2421 & HSBU 201663 \\
\hline 5. G. platypetalum & East Azerbaijan kaleybar & $38^{\circ} 52^{\prime} 39^{\prime \prime}$ & $47^{\circ} 23^{\prime} 92^{\prime \prime}$ & 1144 & HSBU 201668 \\
\hline 6. G. sylvaticum & East Azerbaijan kaleybar cheshme ali akbar & $38^{\circ} 52^{\prime} 39^{\prime \prime}$ & $47^{\circ} 25^{\prime} 92^{\prime \prime}$ & 1133 & HSBU 201669 \\
\hline 7. G. pratense & East Azerbaijan kaleybar, Shojabad & $38^{\circ} 52^{\prime} 39^{\prime \prime}$ & $47^{\circ} 25^{\prime} 92^{\prime \prime}$ & 1137 & HSBU 201670 \\
\hline 8. G. ibericum & Mazandaran, Tonekabon-jannat rudbar & $36^{\circ} 48^{\prime} 47^{\prime \prime}$ & $50^{\circ} 53^{\prime} 68^{\prime \prime}$ & 1600 & HSBU 201671 \\
\hline 9. G. gracile & Mazandaran, Noshahr, Kheyrud kenar Forest & $36^{\circ} 38^{\prime} 05^{\prime \prime}$ & $51^{\circ} 29^{\prime} 05^{\prime \prime}$ & 1250 & HSBU 201672 \\
\hline 10. G. persicum & Tehran, Firuz kuh & $35^{\circ} 43^{\prime} 15^{\prime \prime}$ & $52^{\circ} 04^{\prime} 12^{\prime \prime}$ & 1975 & HSBU 201673 \\
\hline 11. G. kotschyi & Alborz, Karaj- Qazvin & $35^{\circ} 49^{\prime} 23^{\prime \prime}$ & $51^{\circ} 00^{\prime} 04^{\prime \prime}$ & 1365 & HSBU 201674 \\
\hline 12. G. tuberosum & East Azerbaijan kaleybar cheshme ali akbar & $38^{\circ} 52^{\prime} 39^{\prime \prime}$ & $47^{\circ} 25^{\prime} 92^{\prime \prime}$ & 1133 & HSBU 201675 \\
\hline 13. G. stepporum & Tehran, Tuchal & $35^{\circ} 50^{\prime} 03^{\prime \prime}$ & $51^{\circ} 24^{\prime} 28^{\prime \prime}$ & 2383 & HSBU 201676 \\
\hline
\end{tabular}




\section{Materials and methods}

\section{Plant materials}

We performed morphological and molecular analysis of 13 Geranium species growing in Iran (Table 1). For morphometric studies we used 159 plant specimens (7-35 samples from each species) (Figure 2), and for ISSR analysis, we used 102 (Figure 5). The species studied are: G. columbinum L., G. rotundifolium L., G. collinum Stephan ex Willd, G. sylvaticum L., G. pratense (sec. Geranium); G. dissectum L. (sec. Dissecta); G. persicum Schönb.Tem., G. tuberosum L., G. kotschyi Boiss., G. stepporum P.H.Davis (sec. Tuberosa subsect. Tuberosa (Boiss.) Yeo); G. platypetalum Fisch. \& C. A. Mey., G. gracile Ledeb. ex Nordm., G. ibericum Cav. (sec. Tuberosa subsect. Mediterranea R. Knuth). Different references were used for the correct identification of species (Davis 1967, Schonbeck-Temesy 1970, Zohary 1972, Aedo et al. 1998b, Janighorban 2009). Details of sampling sites are mentioned (Table 1, Figure 1). Voucher specimens are deposited in Herbarium of Shahid Beheshti University (HSBU).

\section{Morphological studies}

In total 80 morphological ( 42 qualitative, 38 quantitative) characters were studied (supplementary Table 2). Data obtained were standardized (Mean $=0$, variance $=1$ ) and used to estimate Euclidean distance for clustering and ordination analyses (Podani 2000).

\section{DNA extraction and issr assay}

Fresh leaves were used randomly from 5-11 plants in each of the studied species. These were dried by silica gel powder. CTAB activated charcoal protocol was used to extract genomic DNA, (Sheidai et al., 2013). The quality of extracted DNA was examined by running on $0.8 \%$ agarose gel. 10 ISSR primers; (AGC) 5GT, (CA) 7GT, (AGC) 5GG, UBC 810, (CA) 7AT, (GA) 9C, UBC 807, UBC 811, (GA) 9T and (GT) 7CA commercialized by UBC (the University of British Columbia) were used. PCR reactions were carried in a $25 \mu \mathrm{l}$ volume containing $10 \mathrm{mM}$ Tris- $\mathrm{HCl}$ buffer at $\mathrm{pH} 8 ; 50 \mathrm{mM} \mathrm{KCl} ; 1.5$ $\mathrm{mM} \mathrm{MgCl}_{2} ; 0.2 \mathrm{mM}$ of each dNTP (Bioron, Germany); $0.2 \mu \mathrm{M}$ of a single primer; $20 \mathrm{ng}$ genomic DNA and $3 \mathrm{U}$ of Taq DNA polymerase (Bioron, Germany). The amplifications' reactions were performed in Techne thermocycler (Germany) with the following program: 5 min initial denaturation step $94^{\circ} \mathrm{C}$, followed by 40 cycles of $1 \mathrm{~min}$ at $94^{\circ} \mathrm{C} ; 1 \mathrm{~min}$ at $52-57^{\circ} \mathrm{C}$ and $2 \mathrm{~min}$ at $72^{\circ} \mathrm{C}$. The reaction was completed by final extension step of $7-10 \mathrm{~min}$ at
$72{ }^{\circ} \mathrm{C}$. The amplification products were observed by running on $1 \%$ agarose gel, followed by the ethidium bromide staining. The fragment size was estimated by using a 100 bp molecular size ladder (Fermentas, Germany).

\section{Data analyses \\ Morphological studies}

Morphological characters were first standardized (Mean $=0$, Variance $=1)$ and used to establish Euclidean distance among pairs of taxa (Podani 2000). For grouping of the plant specimens, the UPGMA (Unweighted paired group using average) and Ward (Minimum spherical characters) as well as ordination methods of MDS (Multidimensional scaling) and PCoA (Principal coordinate analysis) were used (Podani 2000). ANOVA (Analysis of variance) were performed to show morphological difference among the populations while, PCA (Principal components analysis) biplot was used to identify the most variable morphological characters among the studied populations (Podani 2000). PAST version 2.17 (Hammer et al. 2012) was used for multivariate statistical analyses of morphological data.

\section{Molecular analyses}

ISSR bands obtained were coded as binary characters (presence $=1$, absence $=0$ ) and used for genetic diversity analysis. Parameter like Nei's gene diversity $(\mathrm{H})$, Shannon information index (I), number of effective alleles, and percentage of polymorphism were determined (Weising et al. 2005, Freeland et al. 2011). Nei's genetic distance among populations was used for Neighbor Joining (NJ) clustering and Neighbor-Net networking (Freeland et al. 2011, Huson \& Bryant 2006). Mantel test checked the correlation between geographical and genetic distance of the studied populations (Podani 2000). These analyses were done by PAST ver. 2.17 (Hammer et al. 2012), DARwin ver. 5 (2012) and SplitsTree4 V4.13.1 (2013) software. AMOVA (Analysis of molecular variance) test (with 1000 permutations) as implemented in GenAlex 6.4 (Peakall and Smouse 2006), and Nei's Gst analysis as implemented in GenoDive ver.2 (2013) (Meirmans \& Van Tienderen 2004) were used to show genetic difference of the populations. Moreover, populations genetic differentiation was studied by G'ST est = standardized measure of genetic differentiation (Hedrick 2005), and D_est = Jost measure of differentiation (Jost 2008).

The genetic structure of populations was studied by Bayesian based model STRUCTURE analysis (Pritchard et al. 2000), and maximum likelihood-based method of K-Means clustering of GenoDive ver. 2. (2013). For 
Table 2: Morphological characters in studied species.

Table 2: Morfološke značilnosti preučevanih vrst.

\begin{tabular}{|c|c|}
\hline No. Characters & No. Characters \\
\hline 1 Plant height $(\mathrm{mm})$ & 41 State of stem strength \\
\hline 2 Length of stem leaves petiole $(\mathrm{mm})$ & 42 State of stem branches \\
\hline 3 Length of stem leaves ( $\mathrm{mm})$ & 43 Leave shape \\
\hline 4 Width of stem leaves (mm) & 44 Phyllotaxy \\
\hline 5 Length of stem leaves / Width of stem leaves (mm) & 45 Leaf tips \\
\hline 6 Width of stem leaves/ Length of stem leaves ( $\mathrm{mm})$ & 46 Shape of segments basal leaves \\
\hline 7 Number of segment stem leaves (mm) & 47 Stamen filament color \\
\hline 8 Length of basal leaves petiole $(\mathrm{mm})$ & 48 Stigma hair \\
\hline 9 Length of basal leaves ( $\mathrm{mm}$ ) & 49 Mericarp shape \\
\hline 10 Width of basal leaves $(\mathrm{mm})$ & 50 Mericarp surface \\
\hline 11 Length of basal leaves / Width of basal leaves (mm) & 51 Mericarp hair \\
\hline 12 Width of basal leaves / Length of basal leaves (mm) & 52 Mericarp Rostrum hair \\
\hline 13 Number of segment basal leaves & 53 Sepale hair \\
\hline 14 Calyx length (mm) & 54 Sepale hair density \\
\hline 15 Calyx width (mm) & 55 Peduncle and pedicel hair \\
\hline 16 Calyx length/ Calyx width (mm) & 56 Anthers color \\
\hline 17 Petal length $(\mathrm{mm})$ & 57 Stem hair \\
\hline 18 Petal width (mm) & 58 Stem hair density \\
\hline 19 Petal length / Petal width (mm) & 59 Leaf hair \\
\hline 20 Mericarp length $(\mathrm{mm})$ & 60 Bract shape \\
\hline 21 Mericarp width $(\mathrm{mm})$ & 61 Stipules shape \\
\hline 22 Mericarp length/ Mericarp width (mm) & 62 Bract and Stipules hair density \\
\hline 23 Seed length (mm) & 63 Bract and Stipules hair \\
\hline 24 Seed width $(\mathrm{mm})$ & 64 Shape of segments cauline leaves \\
\hline 25 Seed length/ Seed width $(\mathrm{mm})$ & 65 Shape of calyx \\
\hline 26 Stipules length $(\mathrm{mm})$ & 66 Calyx apex \\
\hline 27 Stipules width (mm) & 67 Petal shape \\
\hline 28 Stipules length/ Stipules width (mm) & 68 State of petale ligule \\
\hline 29 Bract length $(\mathrm{mm})$ & 69 Shape of petal lobes \\
\hline 30 Bract width (mm) & 70 State of petale ligule hair \\
\hline 31 Bract length / Bract width (mm) & 71 Stamen filament hair \\
\hline 32 Pedicel length $(\mathrm{mm})$ & 72 Mericarp hair density \\
\hline 33 Peduncle length (mm) & 73 Mericarp color \\
\hline 34 Rostrum length (mm) & 74 Seed color \\
\hline 35 Style length (mm) & 75 Seed shape \\
\hline 36 Stamen filament length $(\mathrm{mm})$ & 76 Seed surface ornamentation \\
\hline 37 Fruit length (mm) & 77 Peduncle and pedicel hair density \\
\hline 38 Number of flowers per inflorescence & 78 Petioles hair \\
\hline 39 Type root & 79 Petioles hair density \\
\hline 40 Vegetation-forms & 80 Leaf hair density \\
\hline
\end{tabular}

STRUCTURE analysis, data were scored as dominant markers (Falush et al. 2007). The Evanno test was performed on STRUCTURE result to determine proper number of $K$ by using delta $K$ value (Evanno et al. 2005). In K-Means clustering, two summary statistics, pseudo-F, and Bayesian Information Criterion (BIC), provide the best fit for k (Meirmans 2012).

Gene flow was determined by (i) Calculating $\mathrm{Nm}$ an estimate of gene flow from Gst by PopGene ver. 1.32 (1997) as: $\mathrm{Nm}=0.5$ (1 - Gst) / Gst. This approach considers equal amount of gene flow among all populations. (ii) Population assignment test based on maximum likelihood as performed in Genodive ver. in GenoDive ver. 2. (2013). The presence of shared alleles was determined by drawing the reticulogram network based on the least square method by DARwin ver 5. (2012). 


\section{Results}

\section{Species identification and inter- relationship}

\section{Morphometry}

ANOVA showed significant differences $(\mathrm{P}<0.01)$ in quantitative morphological characters among the species studied. In order to determine the most variable characters among the taxa studied, PCA analysis has been performed. It revealed that the first three factors comprised over $62 \%$ of the total variation. In the first PCA axis with $32 \%$ of total variation, such characters as shape of bract, peduncle and pedicel hair, stem hair, bract and leaf hair, petiole hair, mericarp hair density have shown the highest correlation ( $>0.7)$, length of bract and peduncle, width of petal, sepal hair, number of flowers per inflorescence were characters influencing PCA axis 2 and 3 respectively.

Different clustering and ordination methods produced similar results therefore, UPGMA clustering and PCA plot of morphological characters are presented here
(Figures 2, 3). In general, plant samples of each species belong to a distinct section, were grouped together and formed separate cluster. This result show that morphological characters studied can differntiate the Geranium species in two different major clusters or groups. In the studied specimens we did not encounter intermediate forms. In general, two major clusters were formed in UPGMA tree (Figure 2), Populations of G. platypetalum, $G$. gracile and G. ibericum (sect. Tuberosa subsect. Mediterranea) were placed in the first major cluster and were placed with great distance from the other species. The second major cluster included two sub-clusters. Plants of G. persicum, G. tuberosum, G. kotschyi, G.stepporum (sect. Tuberosa subsect. Tuberosa) comprised the first subcluster due to morphological similarity, while plants of $G$. rotundifolium, G. collinum, G. sylvaticum, G. pratense, G. columbinum (sect. Geranium) and G. dissectum (sect. Dissecta) formed the second sub-cluster.

The PCA plot of morphological characters (Figure 3) separated the species into distinct groups with no intermixing. This is in agreement with UPGMA tree presented before.

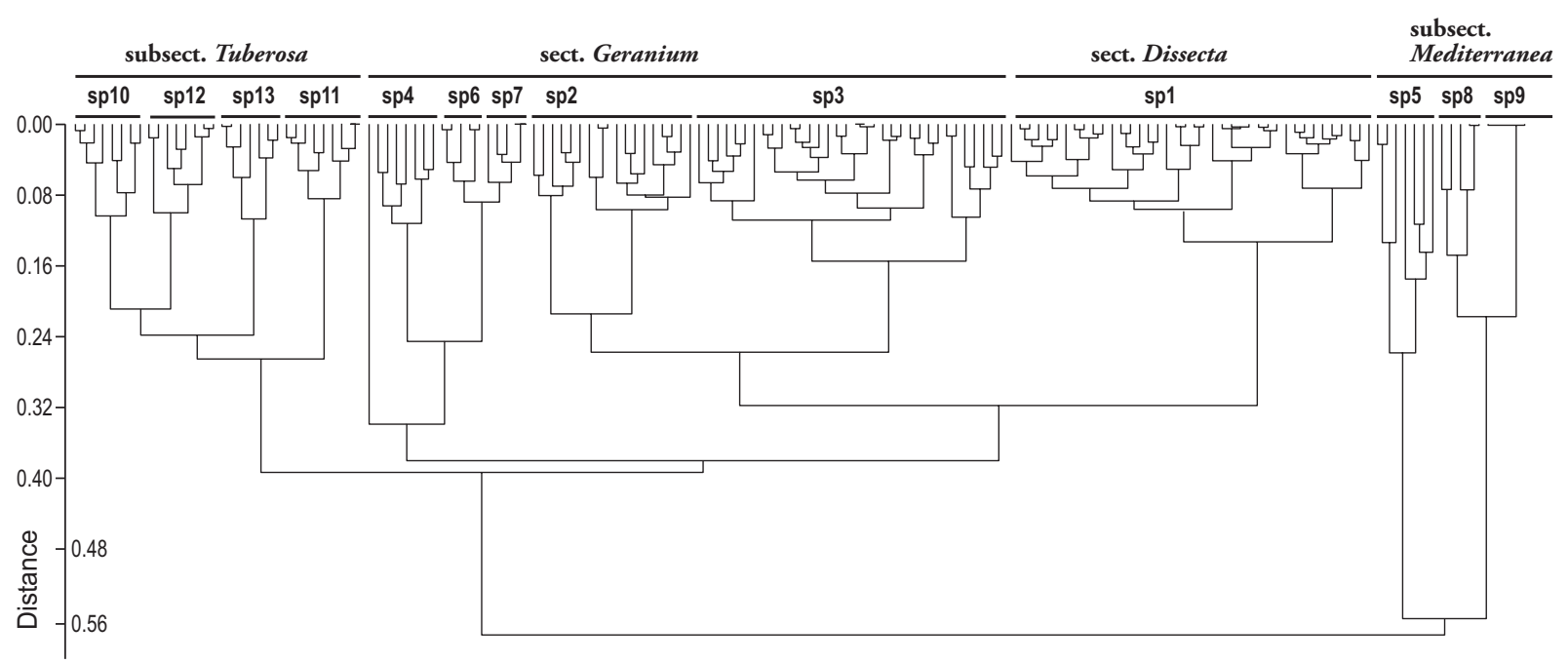

SP1: G. dissectum, SP2: G. columbinum, SP3: G. rotundifolium, SP4: G. collinum, SP5: G. platypetalum, SP6: G. sylvaticum, SP7: G. pratense, SP8: G. ibericum, SP9: G. gracile, SP10: G. persicum, SP11: G. kotschyi, SP12: G. tuberosum, SP13: G. stepporum

Figure 2: UPGMA clustering of morphological characters revealing species delimitation in subg. Geranium. Slika 2: Klasifikacija morofloških značilnosti z metodo UPGMA kaže na ločitev posameznih vrst v subg. Geranium.

\section{Species identification and genetic diversity}

All ISSR primers produced polymorphic bands. Genetic diversity parameters determined in the studied species (Table 3) revealed that $G$. dissectum (sp1) had the high- est level of genetic polymorphism (47.31\%), while the lowest level of genetic polymorphism (2.15\%) occurred in G. gracile and G. tuberosum (sp9, sp13). G. dissectum also had the highest values for effective number of alleles $(\mathrm{Ne}=1.30)$ and Shannon information index $(\mathrm{I}=0.25)$. 


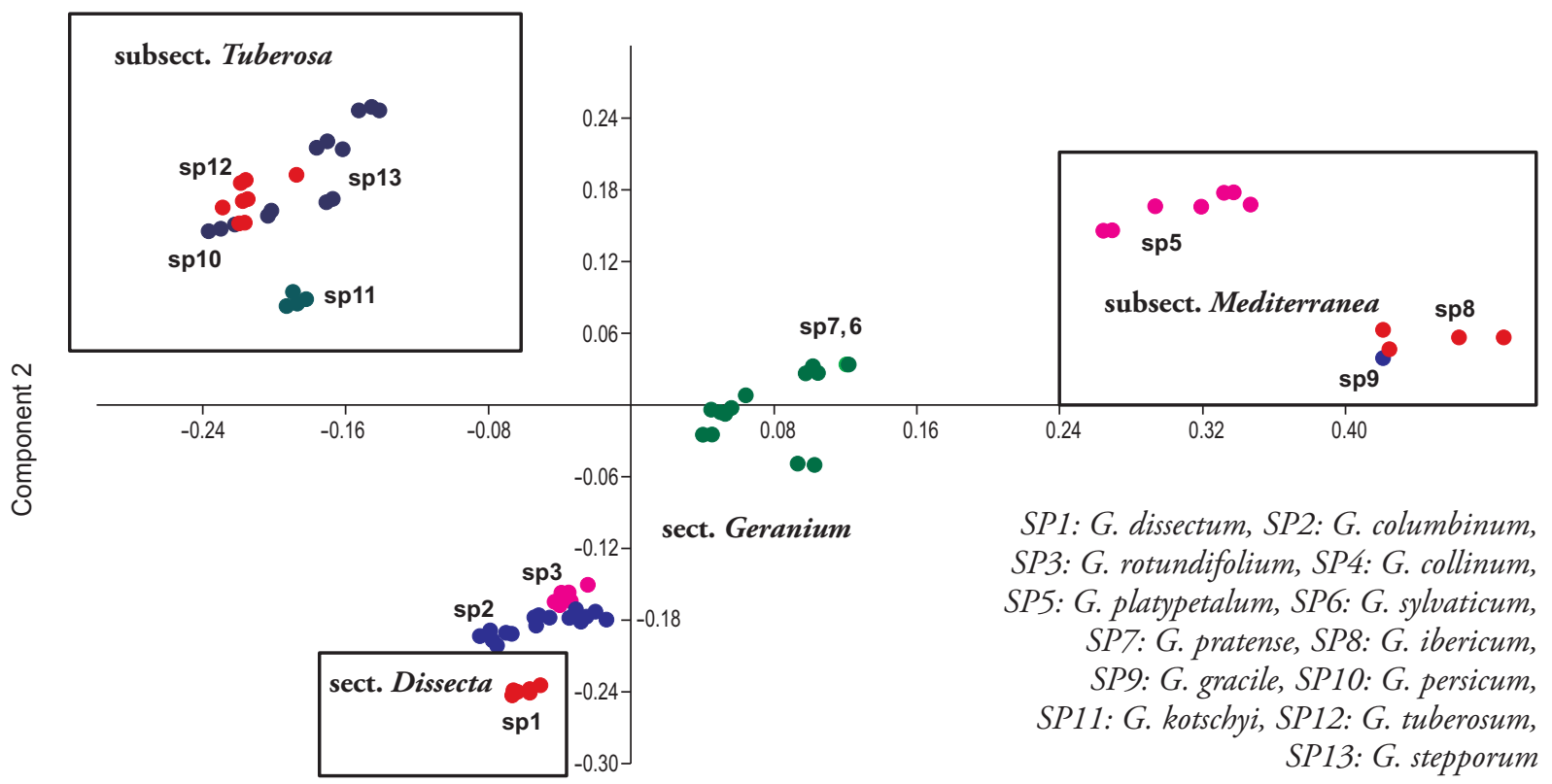

Component 1

Figure 3: PCA plots of morphological characters revealing species delimitation in subg. Geranium.

Slika 3: Diagram PCA morfoloških značilnosti kaže na ločitev posameznih vrst v subg. Geranium.

AMOVA test showed significant genetic difference $(\mathrm{P}=0.01)$ among studied species. It revealed that $79 \%$ of total variation was among species and $21 \%$ was within species. Pair-wise FST values showed significant difference among all studied species (Table 4). Moreover, genetic differentiation of these species was demonstrated by significant Nei's GST $(0.51, \mathrm{P}=0.01)$ and D_est values (0.189, $\mathrm{P}=0.01)$.

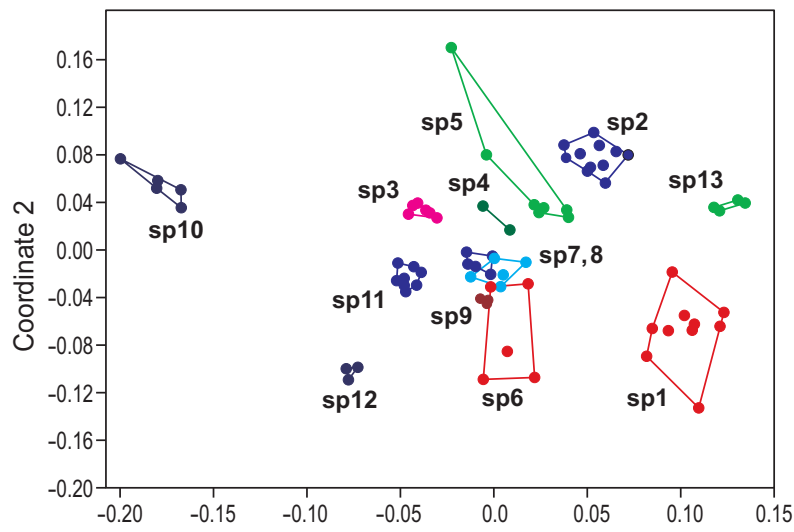

SP1: G. dissectum, SP2: G. columbinum, SP3: G. rotundifolium,

SP4: G. collinum, SP5: G. platypetalum, SP6: G. sylvaticum,

SP7: G. pratense, SP8: G. ibericum, SP9: G. gracile,

SP10: G. persicum, SP11: G. kotschyi, SP12: G. tuberosum,

SP13: G. stepporum

Figure 4: MDS plot of Geranium species based on ISSR data.

Slika 4: Diagram MDS vrst rodu Geranium na podlagi podatkov ISSR.
Non-metric MDS plots of ISSR data (Figure 4) showed higher within species genetic diversity in $G$. dissectum (sp1), supporting genetic diversity parameters obtained (Table 3).

Table 3: Genetic diversity parameters in the studied Geranium species. $(\mathrm{N}=$ number of samples, $\mathrm{Ne}=$ number of effective alleles, I= Shannon's information index, $\mathrm{He}=$ gene diversity, $\mathrm{UHe}=$ unbiased gene diversity, $\mathrm{P} \%=$ percentage of polymorphism, populations).

Tabela 3: Genetska diverziteta spremenljivk preučevanih vrst rodu Geranium. ( $\mathrm{N}=$ število vzorcev, $\mathrm{Ne}=$ efektivno število alelov, I= Shannonov informacijski index, $\mathrm{He}=$ genetska diverziteta, $\mathrm{UHe}=$ nepristranska genetska diverziteta, $\mathrm{P} \%=$ delež polimorfizma, populacij).

\begin{tabular}{|c|c|c|c|c|c|c|c|}
\hline Pop & $\mathbf{N}$ & $\mathrm{Na}$ & $\mathrm{Ne}$ & I & $\mathrm{He}$ & $\mathrm{UHe}$ & $\% P$ \\
\hline sp1 & 10.000 & 0.978 & 1.302 & 0.256 & 0.173 & 0.182 & $47.31 \%$ \\
\hline sp2 & 12.000 & 0.376 & 1.061 & 0.053 & 0.036 & 0.037 & $9.68 \%$ \\
\hline sp3 & 7.000 & 0.355 & 1.029 & 0.031 & 0.019 & 0.021 & $7.53 \%$ \\
\hline sp4 & 8.000 & 0.301 & 1.004 & 0.008 & 0.004 & 0.004 & $3.23 \%$ \\
\hline sp 5 & 7.000 & 0.677 & 1.087 & 0.093 & 0.057 & 0.062 & $23.66 \%$ \\
\hline sp6 & 5.000 & 0.699 & 1.156 & 0.143 & 0.094 & 0.105 & $27.96 \%$ \\
\hline sp7 & 5.000 & 0.376 & 1.054 & 0.055 & 0.035 & 0.039 & $11.83 \%$ \\
\hline sp8 & 5.000 & 0.452 & 1.064 & 0.061 & 0.039 & 0.044 & $12.90 \%$ \\
\hline sp9 & 5.000 & 0.269 & 1.021 & 0.015 & 0.011 & 0.012 & $2.15 \%$ \\
\hline sp10 & 8.000 & 0.548 & 1.013 & 0.023 & 0.012 & 0.012 & $9.68 \%$ \\
\hline sp11 & 9.000 & 0.452 & 1.089 & 0.078 & 0.052 & 0.055 & $15.05 \%$ \\
\hline sp12 & 8.000 & 0.333 & 1.006 & 0.009 & 0.005 & 0.005 & $3.23 \%$ \\
\hline sp13 & 7.000 & 0.323 & 1.010 & 0.011 & 0.007 & 0.007 & $2.15 \%$ \\
\hline
\end{tabular}


Table 4: Pair-wise FST values among the studied Geranium species. (Above diagonal $=$ FST value, bellow diagonal =P value).

Tabela 4: Primerjava parov vrednosti FST med preučevanimi vrstami rodu Geranium (Vrednosti nad diagonalo-FST, vrednosti pod diagonalo-P).

\begin{tabular}{lccccccccccccc} 
& sp1 & sp2 & sp3 & sp4 & sp5 & sp6 & sp7 & sp8 & sp9 & sp10 & sp11 & sp12 & sp13 \\
sp1 & - & 0.010 & 0.010 & 0.010 & 0.010 & 0.010 & 0.010 & 0.010 & 0.010 & 0.010 & 0.010 & 0.010 & 0.010 \\
sp2 & 0.593 & - & 0.010 & 0.010 & 0.010 & 0.010 & 0.010 & 0.010 & 0.010 & 0.010 & 0.010 & 0.010 & 0.010 \\
sp3 & 0.590 & 0.856 & - & 0.010 & 0.010 & 0.020 & 0.010 & 0.010 & 0.010 & 0.010 & 0.010 & 0.010 & 0.010 \\
sp4 & 0.593 & 0.870 & 0.897 & - & 0.010 & 0.010 & 0.010 & 0.010 & 0.010 & 0.010 & 0.010 & 0.010 & 0.010 \\
sp5 & 0.507 & 0.752 & 0.774 & 0.803 & - & 0.010 & 0.010 & 0.010 & 0.010 & 0.010 & 0.010 & 0.010 & 0.010 \\
sp6 & 0.414 & 0.766 & 0.710 & 0.773 & 0.580 & - & 0.030 & 0.010 & 0.010 & 0.010 & 0.010 & 0.010 & 0.020 \\
sp7 & 0.477 & 0.810 & 0.793 & 0.853 & 0.661 & 0.478 & - & 0.010 & 0.010 & 0.010 & 0.010 & 0.010 & 0.010 \\
sp8 & 0.474 & 0.831 & 0.831 & 0.860 & 0.667 & 0.507 & 0.479 & - & 0.030 & 0.010 & 0.010 & 0.010 & 0.010 \\
sp9 & 0.513 & 0.878 & 0.925 & 0.963 & 0.794 & 0.667 & 0.775 & 0.577 & - & 0.010 & 0.010 & 0.010 & 0.010 \\
sp10 & 0.682 & 0.908 & 0.920 & 0.953 & 0.844 & 0.831 & 0.880 & 0.883 & 0.944 & - & 0.010 & 0.010 & 0.010 \\
sp11 & 0.565 & 0.795 & 0.780 & 0.834 & 0.741 & 0.622 & 0.630 & 0.730 & 0.790 & 0.851 & - & 0.010 & 0.010 \\
sp12 & 0.634 & 0.912 & 0.938 & 0.970 & 0.874 & 0.785 & 0.891 & 0.911 & 0.966 & 0.954 & 0.788 & - & 0.010 \\
sp13 & 0.597 & 0.878 & 0.945 & 0.965 & 0.819 & 0.791 & 0.884 & 0.895 & 0.970 & 0.951 & 0.861 & 0.971 & - \\
\hline
\end{tabular}

The MDS plot separated the species into distinct groups. This indicates that ISSR molecular markers can be used in Geranium species differentiation. This is in agreement with AMOVA and genetic diversity parameters presented before. The species are genetically well differentiated from each other. The $\mathrm{Nm}$ analysis by Popgene software also produced mean $\mathrm{Nm}=0.10$, that is considered very low value of gene flow among the studied species.

Mantel test with 5000 permutations showed a significant correlation $(\mathrm{r}=0.16, \mathrm{p}=0.0002)$ between genetic distance and geographical distance, so isolation by distance (IBD) occurred among the Geranium species studied.

Nei's genetic identity and the genetic distance determined among the studied species (Table is not included). The results showed that the highest degree of genetic sim- ilarity (0.94) occurred between G. ibericum and G. gracile (sect. Tuberosa subsect. Mediterranea). The lowest degree of genetic similarity occurred between $G$. persicum and G. columbinum (0.61).

NJ tree based on Nei,s genetic distance (Figure 5), showed that G. kotschyi, G. tuberosum (sect. Tuberosa subsect. Tuberosa) are separated from the other studied species and join the others with a great distance. This dendrogram showed close genetic affinity between G. columbinum, G. rotundifolium, G. collinum (sect. Geranium). Similarly, G. gracile and G. ibericum (subsect. Mediterranea) were placed close to each other, to which, G. platypetalum was joined with some distance. In general, species relationships obtained from ISSR data agrees well with species relationship obtained from morphological characters.

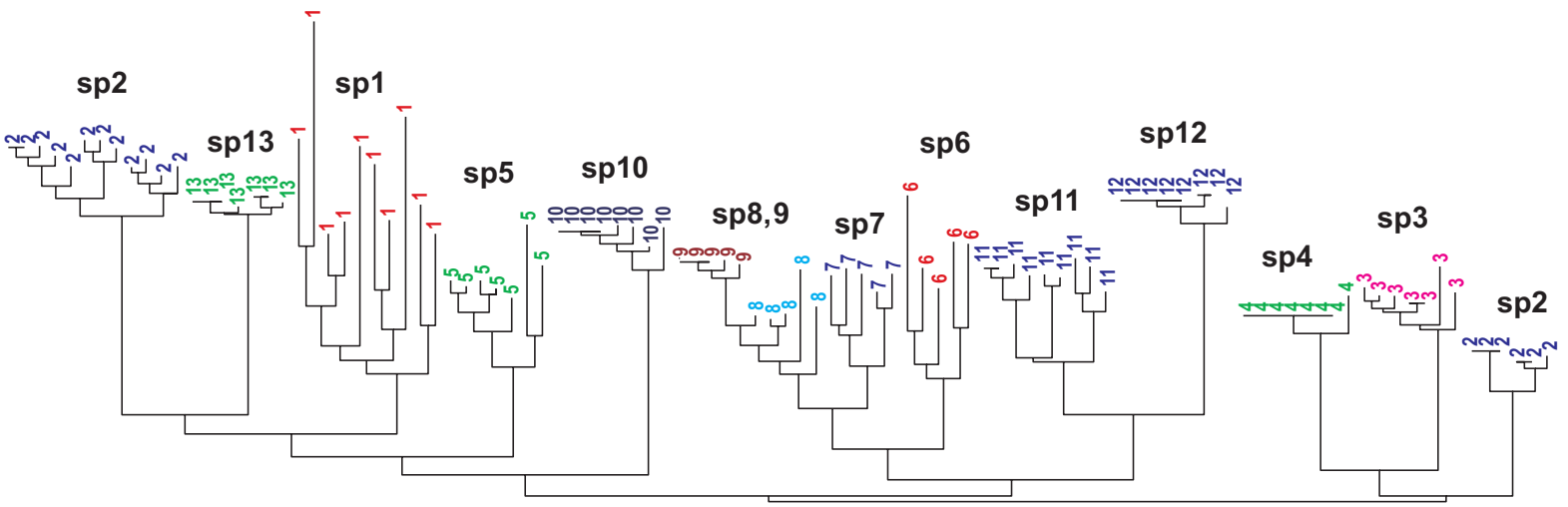

SP1: G. dissectum, SP2: G. columbinum, SP3: G. rotundifolium, SP4: G. collinum, SP5: G. platypetalum,

SP6: G. sylvaticum, SP7: G. pratense, SP8: G. ibericum, SP9: G. gracile, SP10: G. persicum, SP11: G. kotschyi,

SP12: G. tuberosum, SP13: G. stepporum

Figure 5: Neighbor joining tree of inter simple sequence repeats data in the studied Geranium species.

Slika 5: Dendrogram, narejen z združevanjem najbližjega soseda podatkov ISSR preučevanih vrst rodu Geranium. 


\section{The species genetic structure}

We performed STRUCTURE analysis followed by the Evanno test to identify the optimal number of genetic groups. We used the admixture model to illustrate interspecific gene flow or / and ancestrally shared alleles in the species studied.

STRUCTURE analysis followed by Evanno test produced $\Delta \mathrm{K}=10$. The STRUCTURE plot (Figure 6) produced more detailed information about the genetic structure of the species studied as well as shared ancestral alleles and / or gene flow among Geranium species. This plot revealed that Genetic affinity between $G$. rotundifolium and $G$. collinum (similarly colored), as well as G. ibericum and G. gracile (similarly colored) due to shared common alleles. This is in agreement with Neighbor joining dendrogram presented before. The other species are distinct in their allele composition and differed genetically from each other.

The low $\mathrm{Nm}$ value (0.10) indicates limited gene flow or ancestrally shared alleles between the species studied and supports genetic stratification as indicated by K-Means and STRUCTURE analyses. Population assignment test also agreed with $\mathrm{Nm}$ result and could not identify significant gene flow among members of the studied species. However, reticulogram obtained based on the least square method (Figure 7), revealed some amount of shared alleles between species 10 and 11 and between 1 and 8
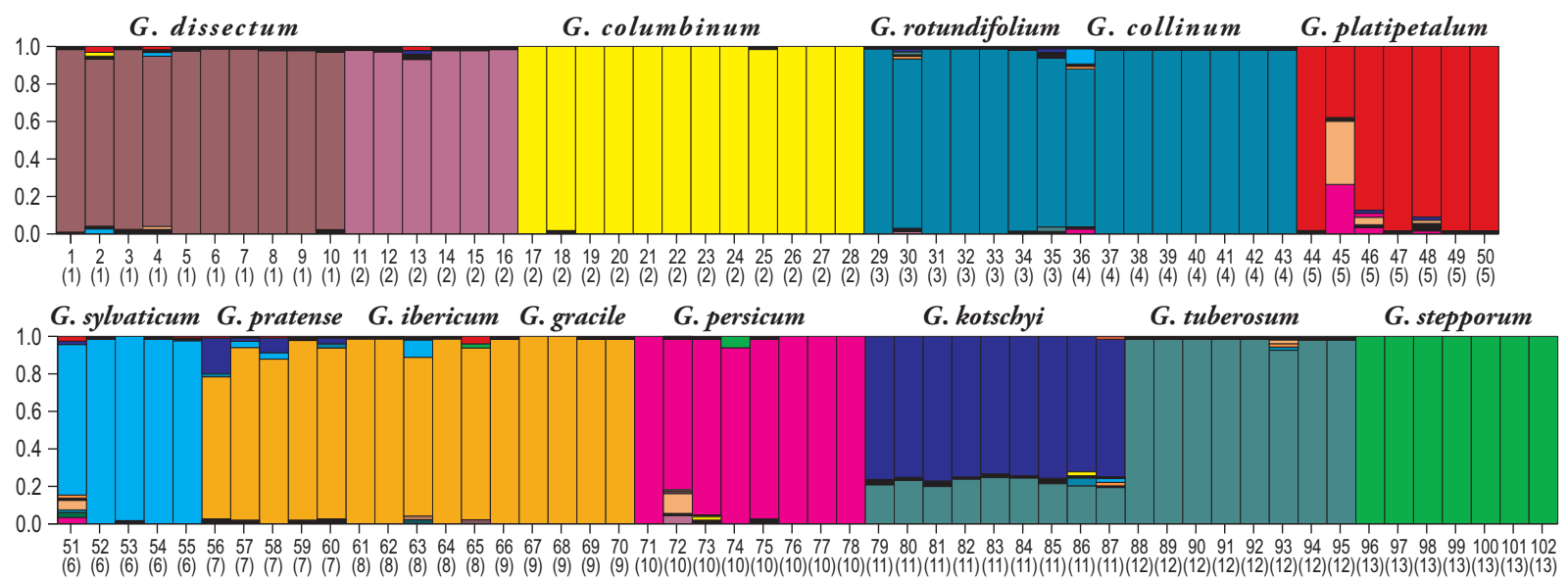

Figure 6: STRUCTURE plot of Geranium species based on ISSR data.

Slika 6: Diagram STRUCTURE vrst rodu Geranium na osnovi podatkov ISSR.

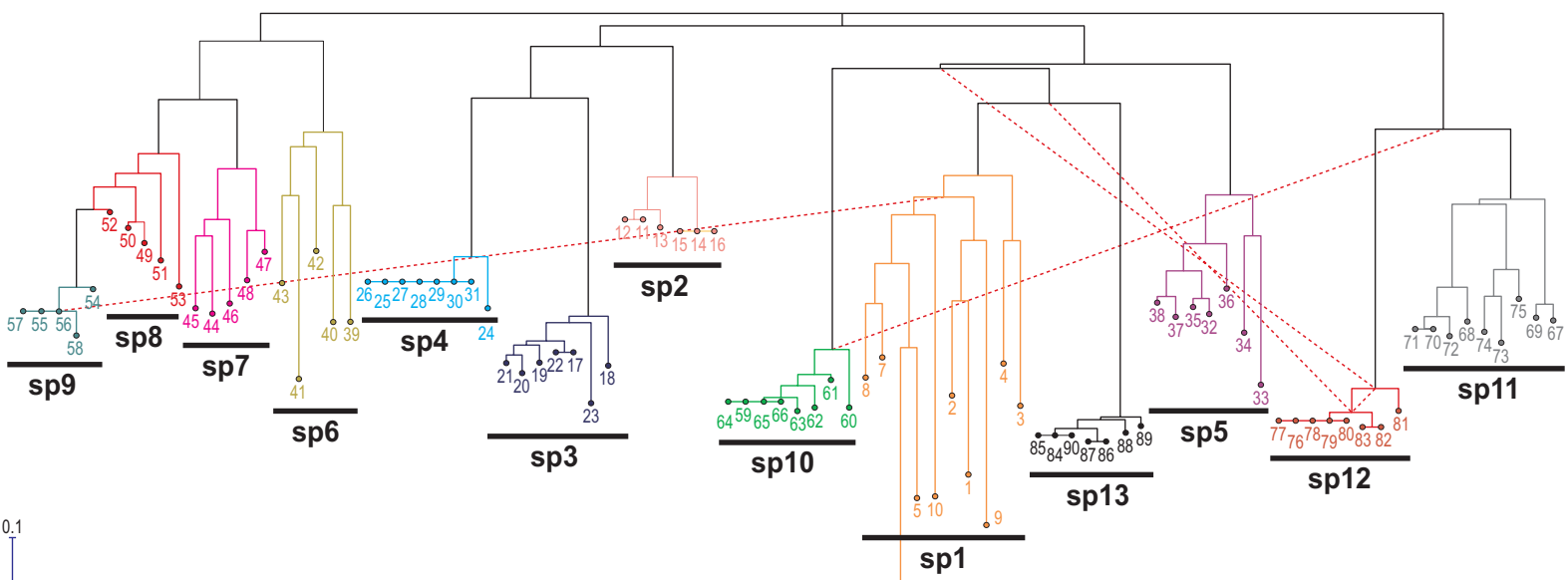

SP1: G. dissectum, SP2: G. columbinum, SP3: G. rotundifolium,

SP4: G. collinum, SP5: G. platypetalum, SP6: G. sylvaticum,

SP7: G. pratense, SP8: G. ibericum, SP9: G. gracile, SP10: G. persicum,

SP11: G. kotschyi, SP12: G. tuberosum, SP13: G. stepporum

Figure 7: Reticulogram of Geranium species. Slika 7: Retikulogram vrst rodu Geranium. 
also between 12 and 1, 10, 13. As evidenced by STRUCTURE plot based on admixture model, these shared alleles comprise very limited part of the genomes in species studied and all these results are in agreement in showing high degree of genetic stratification in species studied

\section{Discussion}

\section{Species identification and taxonomic consideration}

Controversy exists on the number of species in this genus, for example, there is occurring 22 annual and perennial species for this genus in Iran according to Flora Iranica (Schönbeck-Temesy 1970), but in Iran Flora (Janighorban 2009), the genus is represented by 25 species but there are not clarified sections for it (Onsori et al. 2010). Moreover, the present study showed that the subg. Geranium is characterized by a fruit of seed-ejection type, the comprises 13 species in three sections in Iran: 1) Sect. Tuberosa indicating that it differs from the general model of subgen. Geranium in two ways: the awn, with the mericarps attached, falls away from the columella, and there is no structure for retaining the seed in the pre-explosive interval. These important fruit characters seem to support sect. Tuberosa as a natural group, in which two subgroups can be differentiated: a) subsect. Tuberosa with tuberose rootstock and \pm palmatisect leaves, and b) subsect. Mediterranea without tuberose rootstock and palmatifid leaves (Yeo 1984). All species of Geranium subsect. Mediterranea except $G$. bohemicum and $G$. lanuginosum are perennial herbaceous plants. The leaves are polygonal in outline, cordate, palmatifid, with (3-) 5-7 segments. The inflorescence is dichasial, with dichotomous branching and a long pedunculate cymule at the primary branch (Yeo 1984).

The leaves in all species of subsect. Tuberosa are polygonal in outline, cordate, with 5-7(13) segments, They are usually palmatisect, The inflorescence is dichasial, with dichotomous branches and a long pedunculate cymule at the main fork (except in G. kotschyi), 2) sect. Dissecta characterized by the mericarp with the margin at the base drawn out into a prong lacking setae. A multivariate morphometric study showed that some quantitative characters such as deeply divided leaves, palmatifid, with 5-7 segments, shorter and narrower petals and shorter filaments clearly distinguished the annual $G$. dissectum, 3) sect. Geranium characterized by the mericarp with the margin at the base drawn out into a horny setiferous tubercle (Yeo 1984).

Morphological analyses of the studied Geranium species showed that they are well differentiated from each other both in quantitative measures (the ANOVA test result) and qualitative characters (The PCA plot result). In addition, PCA analysis suggests that characters like peduncle length, bract length, stipule length, bract shape, number of flowers per inflorescence, width of petal, peduncle and pedicel hair, leaf and petiole hair, stem hair, stipule and bract hair, habit and petal claw could be used in species groups delimitation. This morphological difference was due to quantitative and qualitative characters, for example, $G$. platypetalum has the longest bract length $(13 \mathrm{~mm})$, the longest stipule length (13-14 mm), the longest peduncle length $(70-100 \mathrm{~mm})$ and the broadest petal width $(16 \mathrm{~mm})$ among the studied species. Similarly, $G$. dissectum and $G$. rotundifolium had the narrowest petal length $(4-4.5 \mathrm{~mm})$ and the narrowest petal width $(1.5-2.5 \mathrm{~mm})$ among the studied species. Yeo (2002: 214) indicated that artificial hybrids between many species of subsect. Mediterranea (including $G$. ibericum and G. platypetalum) have been produced by A. Bremner. However, no names for these hybrids are available except Geranium × magnificum. We did not encounter any intermediate forms throughout the studied area.

\section{Genetic structure and gene flow}

AMOVA and STRUCTURE analysis revealed that the species of this subg. Geranium are genetically differentiated but have some degree of shared common alleles. Several trends in pollination mechanism can be observed in Geranium with gradual transition between them. According to Philipp (1985), most perennial species of Geranium produce large and protandrous flowers, while a slight or null protandry is accompanied by an increased selfing and a reduction in flower size. Selfing is here related to annual or colonizer strategies, which occur in many other taxa (Baker 1955, 1967, Stebbins 1957, 1970, Ambruster 1993). Annual or biennial species with small flowers such as G. lucidum L., G. pusillum L., G. molle L., G. dissectum, G. rotundifolium are expected to be automatically self-pollinated. This has been proved for $G$. molle, G. dissectum. Usually large flowered perennial species rely on insects for pollination. The flowers of $G$. pratense are pollinated by bees, honeybees and bumblebees. The methods we used are indirect estimation of gene flow and if it is identified to occur among species may be either due to ancestral shared alleles or ongoing gene flow. The Nm value obtained based on ISSR data, revealed very limited amount of gene flow among the studied species that was also supported by STRUCTURE analysis as Geranium species mostly had distinct genetic structure. Reticulation analysis also showed some degree of gene flow for ISSR. We did not observe any 
intermediate forms in our extensive plant collection, but morphological variability within each species did occur to some extent.

To conclude, the present study revealed the use of ISSR molecular markers along with morphological characters in Geranium species identification. Some degrees of interspecific genetic admixture occur in Geranium, but the studied species are strongly differentiated during the speciation process and invasion in new habitats. Genetic drift, strong inbreeding and local adaptation are effective evolutionary forces operating in Geranium species and population divergence and adaptation.

Plant species identification is of central importance in phylogenetic systematics, evolution, biogeography and biodiversity. It is significant to infer patterns and mechanisms of speciation and hybridization, the evolutionary process by which new biological species arise and gene flow between closely related phylogenetic species can occur (Schluter 2001, Duminil \& Di Michele 2009). Isolation by distance, local adaptation and gene flow are different mechanisms responsible for species differentiation and genetic diversity (Freeland et al. 2011, Frichot et al. 2013).

\section{References}

Aedo, C., Aldasoro, J. J. \& Navarro, C. 1998b: Taxonomic revision of Geranium L., sections Divaricata Rouy and Batrachioidea W.D.J. Koch (Geraniaceae). Annals of the Missouri Botanical Garden 85: 594-630. DOI: $10.2307 / 2992018$

Aedo, C. \& Estrella, M. D. L. 2006: Taxonomic revision of Geranium subsect. Tuberosa (Boiss.) Yeo. Israel Journal of Plant Sciences 54:19-44.

Aedo, C., Aldasoro, J. J., Sáez L. \& Navarro, C. 2003: Taxonomic revision of Geranium sect. Gracilia (Geraniaceae). Brittonia 55: 93-126.

Aedo, C. 1996: Revision of Geranium subgenus Erodioidea (Geraniaceae). Systematic Botany Monographs 49:1-104.

Aedo, C., Alarcón, M. L., Aldasoro J. J. \& Navarro, C. 2007:

Taxonomic revision of Geranium subsect. Mediterranea (Geraniaceae). Systematic Botany 32: 93-128.

Aedo, C., Fiz, O., Alarcón, M. L., Navarro, C. \& Aldasoro J. J. 2005a: Taxonomic revision of Geranium sect. Dissecta (Geraniaceae). Systematic Botany 30: 533-558.

Aedo, C., Navarro, C. \& Alarcón, M. L. 2005b: Taxonomic revision of Geranium sections Andina and Chilensia (Geraniaceae). Botanical Journal of the Linnean Society 149: 1-68.

Armbruster, W. S. 1993: Evolution of plant pollination systems: hypotheses and tests with the neotropical vine Dalechampia. Evolution 47: $1480-1505$.

Baker, H. G. 1955: Self-compatibility and establishment after "longdistance" dispersal. Evolution 9: 347-349.
Baker, H. G. 1967: Support for Baker's law as a rule. Evolution 21: $85-56$.

Carlquist, S.H. \& Bissing, D. 1976: Leaf anatomy of Hawaiian Geranium in relation by ecology and taxonomy. Biotropica 8: 248-259.

Davis, P.H. 1967: Geranium L. In: P.H. Davis, J.Cullen \& J.E. Coode (eds.), Flora of Turkey, vol 2. University Press, Edinburg 19: 451-474.

Davis, P.H. 1970: Geranium sect. Tuberosa, revision and evolutionary interpretation. Israel Journal of Plant Sciences 19: 91-113.

Duminil, J. \& Di Michele, M. 2009: Plant species delimitation: A comparison of morphological and molecular markers. Plant Biosystems 143: $528-542$.

Esfandani-Bozchaloyi, S., Sheidai, M., Keshavarzi, M. \& Noormohammadi, Z. 2017a: Genetic Diversity and Morphological Variability In Geranium Purpureum Vill. (Geraniaceae) Of Iran. Genetika 49: 543-557. https://doi.org/10.2298/GENSR1702543B

Esfandani-Bozchaloyi, S., Sheidai, M., Keshavarzi, M. \& Noormohammadi, Z. 2017b: Species Delimitation In Geranium Sect. Batrachioidea: Morphological And Molecular. Acta Botanica Hungarica 59(3-4):319-334. doi: 10.1556/034.59.2017.3-4.3

Esfandani-Bozchaloyi, S., Sheidai, M., Keshavarzi, M. \& Noormohammadi, Z. 2017c: Genetic and morphological diversity in Geranium dissectum (Sec. Dissecta, Geraniaceae) populations. Biologia 72(10): 1121-1130. DOI: 10.1515/biolog-2017-0124

Esfandani-Bozchaloyi, S., Sheidai, M., Keshavarzi, M. \& Noormohammadi, Z. 2017d: Analysis of genetic diversity in Geranium robertianum by ISSR markers. Phytologia Balcanica 23(2):157-166.

Evanno, G., Regnaut, S. \& Goudet, J. 2005: Detecting the number of clusters of individuals using the software STRUCTURE: a simulation study. Molecular Ecology 14: 2611-2620.

Falush, D., Stephens, M. \& Pritchard, J.K. 2007: Inference of population structure using multilocus genotype data: dominant markers and null alleles. Molecular Ecology Notes 7: 574-578.

Freeland, J.R., Kirk, H. \& Peterson, S.D. 2011: Molecular Ecology (2nded). Wiley-Blackwell, UK, 449 pp.

Frichot, E., Schoville, S. D., Bouchard, G. \& Francois, O. 2013: Testing for associations between loci and environmental gradients using latent factor mixed models. Molecular Biology and Evolution 30: 1687-1699.

Hammer, Ø., Harper, D.A. \& Ryan, P.D. 2012: PAST: Paleontological Statistics software package for education and data analysis. Palaeontologia Electronica 4: 9.

Hedrick, P. W. 2005: A standardized genetic differentiation measure. Evolution 59:1633-1638.

Huson, D.H. \& Bryant, D. 2006: Application of Phylogenetic Networks in Evolutionary Studies. Molecular Biology and Evolution 23: 254-267.

Janighorban, M. 2009: Flora of Iran. Geraniaceae. Vol. 62. The Research Institute of Forests and Rangelands, 64 pp. [in Persian].

Jost, L. 2008: GST and its relatives do not measure differentiation. Molecular Ecology 17: 4015-4026.

Keshavarzi, M. 2015: Infrageneric classification of Geranium (Geraniaceae) based on fruit and seed morphology. Acta Biologica Szegediensis 59: 45-54. 
Keshavarzi, M., Behzadifar, M. \& Nazem Bokaee, Z. 2016: Pollen morphology of some Geranium subgenus Robertium species of Iran. Modern Phytomorphology 10: 39-45.

Knowles, L.L., \& Carstens, B. 2007: Delimiting species without monophyletic gene trees. Systematic Biology 56: 887-895. doi:10.1080/10635150701701091.

Mayr, E. 1982: The Growth of Biological Thought : Diversity, Evolution, and nheritance. Cambridge, MA: Harvard University Press, 992 pp.

Medrano, M., López-Perea E. \& Herrera, C.M. 2014: Population genetics methods applied to a species delimitation problem: Endemic trumpet daffodils (Narcissus section Pseudonarcissi) from the Southern Iberian Peninsula. International Journal of Plant Sciences 175: 501-517. doi: 10.1086/675977

Meirmans, P.G. \& Van Tienderen, P.H. 2004: GENOTYPE and GENODIVE: two programs for the analysis of genetic diversity of asexual organisms. Molecular Ecology Notes 4: 792-794.

Meirmans, P.G. 2012: AMOVA-based clustering of population genetic data. Journal of Heredity 103: 744-750.

Onsori, S., Salimpour, F. \& Mazooji, A. 2010: The new record of Geranium linearilobum Dc. based on anatomy and micromorphological study of pollen and seed, in Iran. Journal of plant environmental physiology 5: 21-30. [in Persian with English abstract]

Peakall, R. \& Smouse, P.E. 2006: GENALEX 6: genetic analysis in Excel. Population genetic software for teaching and research. Molecular Ecology Notes 6: 288-295.

Pérez-Losada, M., Eiroa, J., Mato, S., \& Domínguez, J. 2005: Phylogenetic species delimitation of the earth worms Eiseniafetide (Savigny,1826) and Eiseniaandrei Bouché, 1972 (Oligochaeta, Lumbricidae) based on mitochondrial and nuclear DNA sequences. Pedobiologia 49: 317-324.doi: 10.1016/j.pedobi.2005.02.004

Philipp, M. 1985: Reproductive biology of Geranium sessiliflorum, 1. Flower and flowering biology. New Zealand Journal of Botany 23: 567-589

Podani, J. 2000: Introduction to the Exploration of Multivariate Data English translation. Backhuyes publisher, Leiden, 407 pp.

Pritchard, J.K., Stephens, M. \& Donnelly, P. 2000: Inference of population structure using multilocus genotype Data. Genetics 155 : 945-959.

Salimi Moghadam, N. 2015: Data from: Micromorphological studies on fruits and seeds of the genus Geranium (Geraniaceae) from Iran and their systematic significance - Dryad Digital Repository < http:// dx.doi.org/10.5061/dryad. h1n71 >.
Salimpour, F., Mazooji, A. \& Onsori, S. 2009: Stem and leaf anatomy of ten Geranium L. species in Iran. African Journal of Plant Science 3: 238-244.

Schluter, D. 2001: Ecology and the origin of species. Trends in Ecology \& Evolution 16: 372-380.

Schönbeck-Temesy, E. 1970: Geraniaceae. In: Rechinger, K.H. ed., Flora Iranica, Vol. 69, pp. 30-58, Akademische Druck, Graz, Austria.

Sheidai, M., Zanganeh, S., Haji-Ramezanali, R., Nouroozi, M., Noormohammadi, Z. \& Ghsemzadeh-Baraki, S. 2013: Genetic diversity and population structure in four Cirsium (Asteraceae) species. Biologia 68: 384-397.

Sites, J.W. \& Marshall, J.C. 2003: Delimiting species: A Renaissance issue in systematic biology. Trends in Ecology \& Evolution 18: 462-470.

Stebbins, G. L. 1957: Self fertilization and population variability in the higher plants. American Naturalist 91: 337-354.

Stebbins, G. L. 1970: Adaptive radiation of reproductive characteristics in angiosperms, I: pollination mechanisms. Annual Review of Ecology and Systematics 1: 307-326.

Weising, K., Nybom, H., Wolff, K. \& Kahl, G. 2005: DNA Fingerprinting in Plants. Principles, Methods, and Applications. 2nd ed. CRC Press, Boca Rayton, 472 pp.

Wiens, J.J. \& Penkrot, T.A. 2002: Delimiting species using DNA and morphological variation and discordant species limits in spinylizards (Sceloporus). Systematic Biology 51: 69-91.

Wiens, J.J. 2007: Species Delimitation: New approaches for discovering diversity. Systematic Biology 56: 875-878. doi:10.1080/10635150701748506.

Yeo, P. F. 1984: Fruit-discharge-type in Geranium (Geraniaceae): its use in classification and its evolutionary implications. Botanical Journal of the Linnean Society 89:1-36. DOI: 10.1111/j.1095 8339.1984. tb00998.x

Yeo, P. F. 2002: Hardy geraniums, ed. 2. Portland, Oregon: Timber Press, 218 pp.

Yeo, P. F. 2004: The morphology and affinities of Geranium sections Lucida and Unguiculata. The Linnean Society of London, Botanical Journal of the Linnean Society 144: 409-429.

Zohary, M. 1972: Flora Palaestina. Platanaceae to Umbelliferae. Vol. 4. The Israel Academy of Sciences and Humanities, Jerusalem, Israel, $656 \mathrm{pp}$. 